\title{
Prevalence and temporal stability of selected clostridial groups in irritable bowel syndrome in relation to predominant faecal bacteria
}

Correspondence

Johanna Maukonen

johanna.maukonen@vtt.fi

Received 21 April 2005

Accepted 26 January 2006

\author{
Johanna Maukonen, ${ }^{1}$ Reetta Satokari, ${ }^{1}$ Jaana Mättö, ${ }^{1}$ Hans Söderlund, ${ }^{1}$ \\ Tiina Mattila-Sandholm ${ }^{2}$ and Maria Saarela ${ }^{1}$ \\ ${ }^{1}$ VTT Biotechnology, PO Box 1000 (Tietotie 2), FIN-02044 VTT, Finland \\ ${ }^{2}$ Valio Ltd, PO Box 30, FIN-00039 Valio, Finland
}

The differences in faecal bacterial population between irritable bowel syndrome (IBS) and control subjects have been reported in several studies. The aim of the present study was to compare the predominant and clostridial faecal microbiota of IBS subjects and healthy controls by applying denaturing gradient gel electrophoresis (DGGE) and a recently developed multiplexed and quantitative hybridization-based technique, transcript analysis with the aid of affinity capture (TRAC). According to the results, the studied clostridial groups (Clostridium histolyticum, Clostridium coccoides-Eubacterium rectale, Clostridium lituseburense and Clostridium leptum) represented the dominant faecal microbiota of most of the studied subjects, comprising altogether $29-87 \%$ of the total bacteria as determined by the hybridized $16 S$ rRNA. The C. coccoides- $E$. rectale group was the dominant subgroup of clostridia, contributing a mean of $43 \%$ of the total bacteria in control subjects and $30 \%$ (constipation type) to $50 \%$ (diarrhoea type) in different IBS symptom category subjects. The proportion of the C. coccoides-E. rectale group was found to be significantly lower in the constipation-type IBS subjects than in the control subjects. DNA-based PCR-DGGE and RNA-based RT-PCR-DGGE analyses targeted to the predominant bacterial population showed considerable biodiversity as well as uniqueness of the microbiota in each subject, in both control and IBS subject groups. The RT-PCR-DGGE profiles of the IBS subjects further indicated higher instability of the bacterial population compared to the control subjects. The observations suggest that clostridial microbiota, in addition to the instability of the active predominant faecal bacterial population, may be involved in IBS.

\section{INTRODUCTION}

The composition of the resident intestinal microbiota varies between individuals, and the predominant population is fairly stable under normal conditions (Zoetendal et al., 1998; Harmsen et al., 2002a; Vanhoutte et al., 2004; Mättö et al., 2005). However, several factors, such as antibiotic therapy, ageing and disease, may cause disturbances in the intestinal balance. Transient disturbance of the intestinal microbiota during antibiotic therapy has been shown in several studies (Edlund \& Nord, 2000; Donskey et al., 2003). Changes in the intestinal microbiota have also been suggested to occur in certain intestinal diseases and disorders, such as inflammatory bowel disease (IBD) (Seksik et al., 2003) and irritable bowel syndrome (IBS) (Madden \& Hunter, 2002). IBS is an intestinal disorder that involves continuous or recurrent intestinal pain or discomfort that is relieved during

Abbreviations: DGGE, denaturing gradient gel electrophoresis; IBD, inflammatory bowel disease; IBS, irritable bowel syndrome; TRAC, transcript analysis with the aid of affinity capture. defecation. In addition, IBS symptoms include bloating, altered stool frequency, form or passage, and passage of mucus (Thompson et al., 1999). The existence of abnormal colonic fermentation in IBS (King et al., 1998) and alleviation of IBS symptoms by eradication of small intestinal bacterial overgrowth by antibiotic therapy (Pimentel et al., 2000), suggest that the intestinal microbiota has a role in IBS. Some studies have reported differences in the faecal bacterial population between IBS and control subjects (Balsari et al., 1982; Bradley et al., 1987; Madden \& Hunter, 2002; Mättö et al., 2005; Malinen et al., 2005). However, the results obtained in earlier studies are partly contradictory, and with the exception of those of Mättö et al. (2005) and Malinen et al. (2005), are based on the culture-based analysis of the microbiota. Therefore, the role of intestinal microbiota in IBS is still poorly known. Since IBS is often linked with extensive gas production in the colon (King et al., 1998), and some bacterial groups are more prone to gas production than others (Cato et al., 1986), the possible role of the composition and/or activity of clostridia and related bacteria in intestinal (im)balance warrants further study. 
The aim of the present study was to compare the diversity and temporal stability of the predominant faecal microbiota, with both DNA- and RNA-based denaturing gradient gel electrophoresis (DGGE), to reveal possible differences between IBS subjects and healthy controls. In addition, the composition, abundance and stability of selected clostridial groups were studied to further assess possible differences.

\section{METHODS}

Samples. Five male and 11 female subjects were included in the IBS subject group (age 24-64 years; mean 45 years). The IBS group consisted of subjects with diarrhoea-dominant (seven subjects), constipation-dominant (six subjects) and alternating (mixed) type (three subjects) symptoms. The control subject group consisted of four male and 12 female subjects that were 26-63 years of age (mean 45 years). The exclusion criterion for both groups was antimicrobial therapy during the 2 months prior to each sampling timepoint. Faecal samples from the 32 subjects were obtained on two occasions 6 months apart ( 0 and 6 months). More detailed information about the IBS and control subject groups, as well as sampling and sample handling, has been described previously by Mättö et al. (2005).

DNA extraction. DNA was extracted from $300 \mathrm{mg}$ of faecal material using the FastDNA Spin Kit for Soil (QBIOgene) according to manufacturer's instructions, with the modification that the bacterial cells were broken with a Fast Prep instrument at $6 \cdot 0 \mathrm{~m} \mathrm{~s}^{-1}$ for $60 \mathrm{~s}$ three times. The isolated DNA was stored at $-20^{\circ} \mathrm{C}$ until examined.

RNA extraction and biotinylation. RNA was extracted from faeces as described elsewhere (Zoetendal et al., 1998) with minor modifications (Satokari et al., 2005), and further purified by using the clean-up protocol of the RNeasy mini kit (Qiagen). Total RNA was quantified by $A_{260}$ measurement, and the purity of RNA was evaluated by agarose gel electrophoresis. Purified RNA used for quantitative analysis (see below) was biotinylated by using Photoprobe biotin (Vector Laboratories). Biotinylation was performed by exposing the RNA to long-wave UV light $(365 \mathrm{~nm})$ for $30 \mathrm{~min}$, and the subsequent purification of the RNA from free biotin was performed according to the manufacturer's instructions, with slight modifications according to Satokari et al. (2005).

Specific quantification of 165 rRNA. Multiplexed quantification of clostridial 16S rRNA was performed with the transcript analysis with the aid of affinity capture (TRAC) technique, according to Satokari et al. (2005). Specific $16 \mathrm{~S}$ rRNA-targeted probes for different groups of clostridia and a universal bacterial probe were used in the study (Table 1). The probes were labelled with 6-FAM (6carboxyfluorescein) at the $5^{\prime}$ end and HPLC-purified. Briefly, the TRAC analysis was performed as follows: RNA (maximum amount 5-10 ng) was denatured at $70{ }^{\circ} \mathrm{C}$ for 2 min and hybridized with all the oligonucleotide probes at $50{ }^{\circ} \mathrm{C}$ for $1 \mathrm{~h}$. After hybridization, the biotin-nucleic acid probe complexes were captured on magnetic streptavidin-coated microparticles and washed. The hybridized probes were eluted, and their identity and quantity were determined by capillary electrophoresis with an ABI PRISM 3100 genetic analyser. The signal intensities of the recorded probes corresponded to the amount of target nucleic acid in the mixture, while the size indicated the target. Results were expressed as the percentage of total bacterial $16 \mathrm{~S}$ rRNA that was detected by the Bact338-IIA probe, and as the mean \pm SD of triplicate measurements.

PCR and RT-PCR. Partial 16S rRNA genes were PCR-amplified using primers U968-f+GC and U1401-r (Table 1), as described by Mättö et al. (2005). RT-PCR was performed with the Qiagen OneStep RT-PCR kit according to the manufacturer's instructions, with or without a Q-solution. Primers used for the RT-PCR were the same as those used for the PCR (Table 1). The PCR programme consisted of reverse transcription performed at $50{ }^{\circ} \mathrm{C}$ for $30 \mathrm{~min}$,

Table 1. Probes and primers used

\begin{tabular}{|c|c|c|c|c|}
\hline Target group & Short name & Probe/primer & Sequence $\left(5^{\prime} \rightarrow 3^{\prime}\right)$ & Reference \\
\hline C. lituseburense group $^{\star}$ & Clit group & Clit135 & GTTATCCGTGTGTACAGGG & Franks et al. (1998) \\
\hline C. histolyticum group $\dagger$ & Chis group & Chis1509 & TTATGCGGTATTAATCTYCCTTT & Franks et al. (1998) \\
\hline C. coccoides-E. rectale group $\ddagger$ & Erec group & Erec482-5A & GCTTCTTAGTCARGTACCGAAAAA & $\begin{array}{l}\text { Franks et al. (1998); } \\
\text { Satokari et al. (2005) }\end{array}$ \\
\hline C. leptum group\$ & Clept group & Clept1240 & GTTTTRTCAACGGCAGTC & Sghir et al. (2000) \\
\hline Bacteria & & Bact338-IIA $₫ * *$ & GCTGCCTCCCGTAGGAGTIIA & $\begin{array}{l}\text { Amann et al. (1990); } \\
\text { Satokari et al. (2005) }\end{array}$ \\
\hline Bacteriall & & U968-f + GC†† & $\begin{array}{l}\text { CGCCCGGGGCGCGCCCCGGGCGG- } \\
\text { GGCGGGGGCACGGGGGGAACGC- } \\
\text { GAAGAACCTTA }\end{array}$ & Nübel et al. (1996) \\
\hline Bacteriall & & $\mathrm{U} 1401-\mathrm{r} \dagger \dagger$ & CGG TGT GTA CAA GAC CC & Nübel et al. (1996) \\
\hline
\end{tabular}

${ }^{*}$ Clostridial phylogenetic cluster XI (Collins et al., 1994).

$†$ Clostridial phylogenetic clusters I and II (Collins et al., 1994).

$\ddagger$ Clostridial phylogenetic clusters XIVa and XIVb (Collins et al., 1994).

$\S$ Clostridial phylogenetic cluster IV (Collins et al., 1994).

IIPartial $16 \mathrm{~S}$ rRNA gene $\left(\mathrm{V}_{6}-\mathrm{V}_{8}\right.$ hypervariable region).

IUsed as a probe in the quantitative TRAC analysis.

\#The Erec482 (Franks et al., 1998) probe was tailed with an additional AAAAA sequence (Erec482-5A) at the 3' end for size-distinction purposes.

${ }^{*}$ The Bact338 (Amann et al., 1990) probe was tailed with an additional IIA sequence (Bact338-IIA, where I is inosine) at the $3^{\prime}$ end for sizedistinction purposes.

$\dagger \dagger$ Used as a primer in PCR-DGGE and RT-PCR-DGGE. 
followed by denaturation at $95^{\circ} \mathrm{C}$ for $15 \mathrm{~min}$. Thereafter, the RTPCR programme was similar to the PCR programme: 35 cycles of denaturing at $94^{\circ} \mathrm{C}$ for $30 \mathrm{~s}$, primer annealing at $50{ }^{\circ} \mathrm{C}$ for $20 \mathrm{~s}$ and elongation at $72{ }^{\circ} \mathrm{C}$ for $40 \mathrm{~s}$, and final extension for $10 \mathrm{~min}$ at $72{ }^{\circ} \mathrm{C}$.

DGGE analysis of 165 rDNA fragments. DGGE analysis was performed as described by Mättö et al. (2005). The similarity of the PCR-DGGE profiles of the samples obtained from a single subject at different time-points was compared to evaluate the temporal stability of the predominant faecal bacterial population. The comparison of the profiles was performed by visual inspection of the gels by two researchers and by calculating the similarity percentage using BioNumerics software version 3.0 (Applied Maths BVBA). Clustering was performed with Pearson correlation and the unweighted pair group method with arithmetic mean (UPGMA). Amplicons with a total surface area of at least $1 \%$ were included in the similarity analysis. Similarity value thresholds indicating stable, rather stable and unstable DGGE profiles were determined according to the visual inspection. A DGGE profile was defined as stable if profiles at different time-points were identical (had the same amplicons and no/minor intensity differences), rather stable if they were similar (had differences in presence and intensity of few amplicons), and unstable if the profiles were different (had differences in presence and intensity of several amplicons). Similarity value thresholds for RNA-based and DNA-based profiles were determined separately.

Statistical analysis. The mean and standard deviation were calculated for each experiment. Student's $t$ test (two-sample assuming unequal variances) was used for the statistical analysis of the results.

\section{RESULTS AND DISCUSSION}

In this study, the predominant and clostridial faecal microbiota of IBS subjects and healthy controls were compared to reveal possible differences in the composition, abundance and stability of selected groups. Mättö et al. (2005) have shown by DNA-based analysis that IBS subjects have more instability in their predominant faecal microbiota than healthy controls. We broadened the study by examining whether the instability which was seen in the DNA-based analysis could also be seen in RNA-based analyses, both predominant microbiota and clostridia-targeted. In addition to stability, the composition and abundance of the selected clostridial groups were studied. Clostridia were selected as a target group in this study, since disturbed metabolism of intestinal gases, as well as increased sensitivity of the colon, has been associated with IBS symptoms (King et al., 1998). Since clostridia are able to produce gas, they may play a role in IBS symptoms (Cato et al., 1986).

\section{Temporal stability of predominant bacterial populations}

The temporal intraindividual stability of the predominant bacteria was studied with DNA-based PCR-DGGE and RNA-based RT-PCR-DGGE to determine whether the stability/instability of clostridial populations corresponded with the stability/instability of the predominant bacterial population, and if any differences could be observed between control and IBS subjects (Fig. 1). DNA-based PCRDGGE and RNA-based RT-PCR-DGGE analyses targeted to the predominant bacterial population showed considerable intraindividual biodiversity, as well as uniqueness of

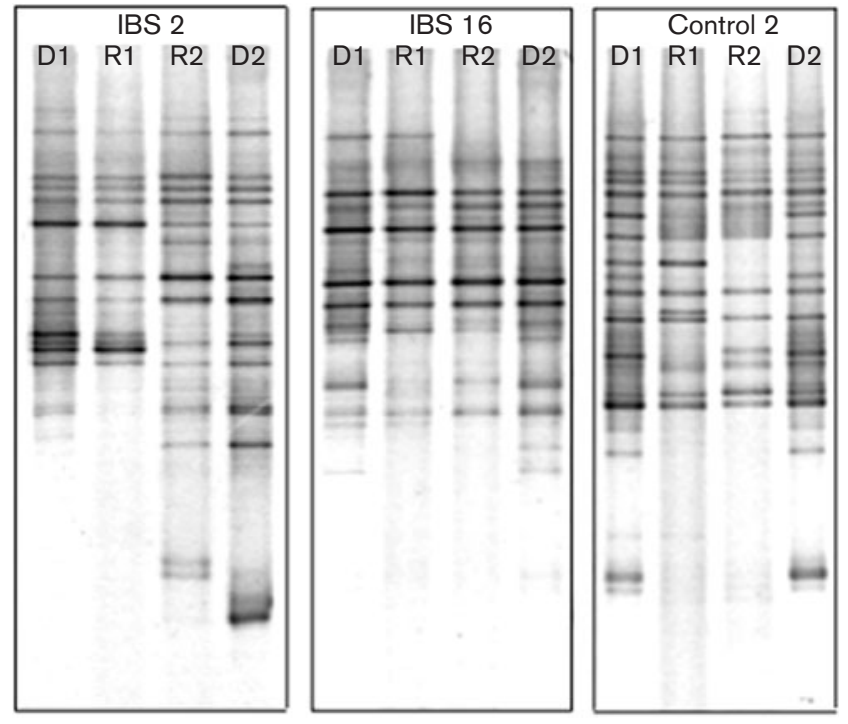

Fig. 1. Comparison of DNA-based PCR-DGGE and RNA-based RT-PCR-DGGE profiles during a 6 month time-period for two IBS subjects and one control subject. Lanes D1 correspond to DNA-based DGGE profiles at baseline, lanes R1 to RNA-based DGGE profiles at baseline, lanes R2 to RNA-based DGGE profiles 6 months later and lanes D2 to DNA-based DGGE profiles 6 months later. The panels are from different individuals with IBS (IBS2 and IBS16) and from a healthy control (Control 2).

the faecal microbiota in both control and IBS subject groups in this study. PCR-DGGE and RT-PCR-DGGE analysis with universal bacterial primers did not reveal any IBS-specific amplicons. PCR-DGGE and RT-PCR-DGGE profiles were heterogeneous, containing about $20-30$ and $15-25$ amplicons, respectively. The RT-PCR-DGGE profiles of IBS subjects ( $16 \pm 5$ amplicons) and control subjects ( $16 \pm 4$ amplicons) contained significantly fewer amplicons than the PCR-DGGE profiles (IBS subjects, $21 \pm 5$ amplicons; control subjects, $23 \pm 5$ amplicons $)(P<0 \cdot 05$; Fig. 1$)$. There were differences in all parts of the denaturing gradient. Some amplicons were more prominent in the RNA-derived profile than in the DNA-derived profile, and vice versa. In addition, some bands were missing from the RNA-derived profiles and some from the DNA-derived profiles. Furthermore, the amplicons with the highest GC content (migrating to the lower part of the DGGE gel) were mostly missing in the RT-PCR-DGGE profiles (Fig. 1). The clear difference between the DNA- and RNA-derived predominant faecal bacterial populations has also been reported by Tannock et al. (2004). The differences between the DNA- and RNAderived profiles may be due to several reasons. The resolving power of RT-PCR is limited by the efficiency of RNA-tocDNA conversion (Bustin \& Nolan, 2004). In addition, DNA obtained from complex samples does not reflect metabolic activity (Josephson et al., 1993), whereas rRNA is regarded as an indicator of total bacterial activity (Felske et al., 1997). Therefore, the amplicons that are missing from 
the RNA-derived profiles may reflect a low activity in that part of the faecal microbiota.

When DGGE profiles derived from faecal RNA amplicons were compared to the DGGE profiles derived from faecal DNA amplicons in this study, the temporal intraindividual similarity values of RT-PCR-DGGE and PCR-DGGE profiles were significantly higher than the intraindividual similarity values between DNA- and RNA-based DGGE profiles at a given time-point in nearly all cases $(P<0 \cdot 05$; Table 2). However, since each individual had unique PCRDGGE and RT-PCR-DGGE profiles, the intraindividual RNA- and DNA-based DGGE profiles resembled each other more than the interindividual RNA-based profiles (Fig. 1). In the present study, the assessment of temporal stability of the predominant microbiota with DNA-based PCR-DGGE did not reveal more instability in the IBS subjects than in the control group subjects (Table 2), contrary to the findings of Mättö et al. (2005). However, less similarity (i.e. more instability) was observed in the DGGE profiles derived from faecal RNA amplicons of the IBS subjects than the control subjects (Table 2). In addition, the similarity value range of RNA-derived DGGE profiles of IBS subjects was much larger than that of the control subjects (Table 2). The main difference between the study group of Mättö et al. (2005) and the study group in this study was that we did not include subjects who had received antimicrobial therapy during the 2 months prior to the two sampling time-points, since antibiotic therapy can cause disturbances in the intestinal microbiota (Edlund \& Nord, 2000; Donskey et al., 2003), and may also affect the predominant bacterial groups (Bartosch et al., 2004). Under normal circumstances, the predominant intestinal microbiota of an adult individual has been reported to be fairly stable (Zoetendal et al., 1998, 2001; Seksik et al., 2003; Vanhoutte et al., 2004). The effect of disease on the stability of intestinal microbiota is clearly seen in the study of Seksik et al. (2003), in which a marked instability of the predominant faecal microbiota was observed in four IBD patients. In our study, temporal instability was observed in both IBS and control subjects (with both DNA- and RNA-based DGGE). In previous studies in which the long-term temporal stability of the predominant microbiota from healthy subjects has been assessed, the number of subjects has been limited (one to four individuals) (Zoetendal et al., 1998, 2001; Seksik et al., 2003; Vanhoutte et al., 2004).

The intraindividual similarity values of PCR-DGGE and RT-PCR-DGGE profiles of IBS subjects between timepoints 1 (baseline) and 2 (6 months) varied between 45 and $95 \%$, and between 39 and $95 \%$, respectively, whereas the similarity values of control subjects varied between 59 and $97 \%$, and between 68 and $94 \%$, respectively (Table 2). When IBS patients were divided into subgroups according to their symptoms in our study, the greatest intraindividual variability in DGGE similarity values within the subject group was seen in the diarrhoea-type subgroup and the smallest in the mixed-type subgroup (Table 2). The great intraindividual variation seen in the diarrhoea-type subgroup might be due to different phases of the syndrome. If a patient is experiencing a more symptomatic phase of IBS, the predominant bacterial population might be significantly different to that when symptom-free, in a similar manner to observations for IBD patients (Seksik et al., 2003). However, we did not have data on the symptomatic activity of each IBS subject, so this conclusion remains speculative. Further studies are needed to assess the influence of the more symptomatic phase of the syndrome on the stability of the faecal microbiota. The smallest intraindividual variability in our study, shown by the mixed-type subject group, is at least partly explained by the small number of subjects (three), so further studies are needed with larger patient groups.

\section{Proportion of clostridia}

In the present study, the recently developed TRAC technique (Satokari et al., 2005) allowed the multiplexed quantification of the clostridial groups. The sensitivity of the technique allows as little as $0.05 \mathrm{ng}$ of total RNA to be detected, but the quantification of proportions is limited by the dynamic range of measurement. In practice, it is feasible to measure 100-200-fold differences in the amounts of individual target RNAs (Satokari et al., 2005). According to our results, the studied clostridial groups [Clostridium. histolyticum (probe Chis150), Clostridium coccoidesEubacterium rectale (probe Erec482), Clostridium lituseburense (probe Clit135) and Clostridium leptum (probe Clept1240) groups] represented the dominant faecal microbiota in most of the studied subjects ( 26 out of 32 subjects, including both IBS and control subjects), contributing altogether $29-87 \%$, as determined by the hybridized $16 \mathrm{~S}$ rRNA (Table 3). This is in agreement with other studies, where several clostridial groups have been studied from clone libraries of adult faecal samples (Wilson \& Blitchington, 1996; Suau et al., 1999; Hayshi et al., 2002; Mangin et al., 2004). The proportion of each studied clostridial group showed marked interindividual variation (Table 3).

There were only small differences in the proportions of the C. leptum, C. lituseburense and C. histolyticum groups between IBS and control subjects (Table 3 ). It has been reported that the $C$. lituseburense and $C$. histolyticum groups contribute less than $1 \%$ of the total faecal microbiota of healthy adults (Franks et al., 1998; Harmsen et al., 1999). Our results for the C. lituseburense group (mean 1.5 and $2 \cdot 3 \%$, for the baseline and 6 month samples, respectively) were thus in accordance with the results reported elsewhere. However, we found that the members of the $C$. histolyticum groups contributed a mean of $7 \cdot 4$ and $5.5 \%$ (for baseline and 6 month samples, respectively) of the faecal bacterial microbiota of the 16 healthy control subjects, and $6 \cdot 2$ and $6.5 \%$ (for baseline and 6 month samples, respectively) of the faecal microbiota of the IBS subjects. Satokari et al. (2005) note in their study that the Chis 150 probe and assay conditions employed give approximately $3 \%$ background 
Table 2. Similarity values of DGGE profiles of a given subject obtained at two different time-points (baseline and 6 months later)

The values are grouped according to the RNA similarity/stability. Abbreviations: S, stable; R, rather stable; U, unstable.

\begin{tabular}{|c|c|c|c|c|c|c|c|}
\hline \multirow[t]{2}{*}{ Subject } & \multicolumn{6}{|c|}{ Qualitative DGGE analysis } & \multirow{2}{*}{$\begin{array}{c}\text { Quantitative } \\
\Delta \text { clostridia }(\%) \dagger, \\
1 \text { versus } 2\end{array}$} \\
\hline & \multicolumn{2}{|c|}{$\begin{array}{c}\text { RNA-based similarity*, } \\
1 \text { versus } 2\end{array}$} & \multicolumn{2}{|c|}{$\begin{array}{c}\text { DNA-based similarity }{ }^{\star} \text {, } \\
1 \text { versus } 2\end{array}$} & $\begin{array}{c}\text { Similarity } \\
(\%)^{\star}, \text { RNA1 } \\
\text { versus DNA1 }\end{array}$ & $\begin{array}{c}\text { Similarity } \\
(\%)^{\star}, \text { RNA2 } \\
\text { versus DNA2 }\end{array}$ & \\
\hline \multicolumn{8}{|c|}{ IBS subjects, diarrhoea type } \\
\hline IBS 1 & $94 \cdot 2 \%$ & $S \neq \varsigma$ & $91 \cdot 9 \%$ & $\mathrm{R} \ddagger \|$ & $83 \cdot 2$ & $88 \cdot 6$ & $6 \cdot 7$ \\
\hline IBS 2 & $38 \cdot 5 \%$ & $\mathrm{U}$ & $44 \cdot 6 \%$ & $\mathrm{U}$ & $88 \cdot 3$ & $59 \cdot 5$ & $50 \cdot 2$ \\
\hline IBS 8 & $81 \cdot 0 \%$ & $\mathrm{R}$ & $92 \cdot 0 \%$ & $\mathrm{R}$ & $76 \cdot 8$ & $74 \cdot 1$ & $9 \cdot 0$ \\
\hline IBS 13 & $50 \cdot 1 \%$ & $\mathrm{U}$ & $87 \cdot 7 \%$ & $\mathrm{R}$ & $67 \cdot 7$ & $70 \cdot 8$ & $5 \cdot 1$ \\
\hline IBS 14 & $59 \cdot 9 \%$ & $\mathrm{U}$ & $74 \cdot 4 \%$ & $\mathrm{U}$ & $56 \cdot 0$ & $81 \cdot 9$ & $15 \cdot 5$ \\
\hline IBS 15 & $89 \cdot 6 \%$ & $\mathrm{R}$ & $90 \cdot 1 \%$ & $\mathrm{R}$ & $77 \cdot 0$ & $89 \cdot 0$ & $15 \cdot 3$ \\
\hline IBS 16 & $92 \cdot 5 \%$ & $S$ & $95 \cdot 1 \%$ & S & $84 \cdot 4$ & $89 \cdot 2$ & $3 \cdot 3$ \\
\hline Mean $\pm S D$ & $72 \cdot 3 \pm 22 \cdot 6$ & & $82 \cdot 3 \pm 17 \cdot 9$ & & $76 \cdot 2 \pm 11 \cdot 1$ & $79 \cdot 0 \pm 11 \cdot 4$ & $15 \cdot 0 \pm 16 \cdot 2$ \\
\hline Range & $38 \cdot 5-94 \cdot 2$ & & $44 \cdot 6-95 \cdot 1$ & & $56 \cdot 0-88 \cdot 3$ & $59 \cdot 5-89 \cdot 2$ & $3 \cdot 3-50 \cdot 2$ \\
\hline \multicolumn{8}{|c|}{ IBS subjects, constipation type } \\
\hline IBS 3 & $43 \cdot 1 \%$ & $\mathrm{U}$ & $68 \cdot 0 \%$ & $\mathrm{U}$ & $75 \cdot 3$ & $84 \cdot 8$ & $22 \cdot 3$ \\
\hline IBS 4 & $80 \cdot 5 \%$ & $\mathrm{R}$ & $84 \cdot 3 \%$ & $\mathrm{R}$ & $70 \cdot 6$ & $76 \cdot 4$ & $8 \cdot 0$ \\
\hline IBS 5 & $79 \cdot 0 \%$ & $\mathrm{R}$ & $81 \cdot 3 \%$ & $\mathrm{R}$ & $72 \cdot 0$ & $78 \cdot 8$ & $0 \cdot 5$ \\
\hline IBS 6 & $93 \cdot 4 \%$ & S & $89 \cdot 4 \%$ & $\mathrm{R}$ & $70 \cdot 4$ & $62 \cdot 9$ & $11 \cdot 1$ \\
\hline IBS 9 & $66 \cdot 1 \%$ & $\mathrm{U}$ & $81 \cdot 8 \%$ & $\mathrm{R}$ & $56 \cdot 2$ & $59 \cdot 4$ & $28 \cdot 9$ \\
\hline IBS 119 & -9 & & $83 \cdot 1 \%$ & $\mathrm{R}$ & $65 \cdot 0$ & -9 & $6 \cdot 9$ \\
\hline Mean \pm SD & $72 \cdot 4 \pm 19 \cdot 0$ & & $81 \cdot 3 \pm 7 \cdot 1$ & & $68 \cdot 3 \pm 6 \cdot 8$ & $72 \cdot 5 \pm 10 \cdot 8$ & $13 \cdot 0 \pm 10 \cdot 6$ \\
\hline Range & $43 \cdot 1-93 \cdot 4$ & & $68 \cdot 0-89 \cdot 4$ & & $56 \cdot 2-75 \cdot 3$ & $59 \cdot 4-84 \cdot 8$ & $0 \cdot 5-28 \cdot 9$ \\
\hline \multicolumn{8}{|c|}{ IBS subjects, mixed type } \\
\hline IBS 7 & $94 \cdot 5 \%$ & $S$ & $85 \cdot 7 \%$ & $\mathrm{R}$ & $70 \cdot 6$ & $69 \cdot 4$ & $8 \cdot 0$ \\
\hline IBS 10 & $80 \cdot 6 \%$ & $\mathrm{R}$ & $88 \cdot 0 \%$ & $\mathrm{R}$ & $89 \cdot 5$ & $80 \cdot 7$ & $11 \cdot 7$ \\
\hline IBS 12 & $83 \cdot 2 \%$ & $\mathrm{R}$ & $87 \cdot 7 \%$ & $\mathrm{R}$ & $66 \cdot 8$ & $63 \cdot 4$ & $20 \cdot 2$ \\
\hline Mean \pm SD & $86 \cdot 1 \pm 7 \cdot 4$ & & $87 \cdot 1 \pm 1 \cdot 3$ & & $75 \cdot 6 \pm 12 \cdot 2$ & $71 \cdot 1 \pm 8 \cdot 8$ & $13 \cdot 3 \pm 6 \cdot 3$ \\
\hline Range & $85 \cdot 7-88 \cdot 0$ & & $85 \cdot 7-88 \cdot 0$ & & $66 \cdot 8-89 \cdot 5$ & $63 \cdot 4-80 \cdot 7$ & $8 \cdot 0-20 \cdot 2$ \\
\hline \multicolumn{8}{|c|}{ All IBS subjects together } \\
\hline Mean \pm SD & $75 \cdot 1 \pm 19 \cdot 0$ & & $82 \cdot 8 \pm 12 \cdot 3$ & & $73 \cdot 1 \pm 10 \cdot 0$ & $75 \cdot 3 \pm 10 \cdot 7$ & $13 \cdot 9 \pm 12 \cdot 2$ \\
\hline Range & $38 \cdot 5-94 \cdot 5$ & & $44 \cdot 6-95 \cdot 1$ & & $56 \cdot 0-89 \cdot 5$ & $59 \cdot 4-89 \cdot 2$ & $0 \cdot 5-50 \cdot 2$ \\
\hline \multicolumn{8}{|c|}{ Control subjects } \\
\hline Control 1 & $85 \cdot 9 \%$ & $\mathrm{R}$ & $88 \cdot 8 \%$ & $\mathrm{R}$ & $75 \cdot 1$ & $70 \cdot 7$ & $13 \cdot 0$ \\
\hline Control 2 & $66 \cdot 0 \%$ & $\mathrm{U}$ & $91 \cdot 3 \%$ & $\mathrm{R}$ & $73 \cdot 2$ & $64 \cdot 6$ & $29 \cdot 8$ \\
\hline Control 3 & $87 \cdot 8 \%$ & $\mathrm{R}$ & $90 \cdot 0 \%$ & $\mathrm{R}$ & $85 \cdot 9$ & $84 \cdot 7$ & $42 \cdot 0$ \\
\hline Control 4 & $92 \cdot 9 \%$ & $S$ & $86 \cdot 7 \%$ & $\mathrm{R}$ & $83 \cdot 6$ & $86 \cdot 4$ & $10 \cdot 5$ \\
\hline Control 5 & $72 \cdot 2 \%$ & $\mathrm{R}$ & $90 \cdot 1 \%$ & $\mathrm{R}$ & $88 \cdot 7$ & $75 \cdot 3$ & $8 \cdot 6$ \\
\hline Control 6 & $94 \cdot 2 \%$ & S & $88 \cdot 4 \%$ & $\mathrm{R}$ & $81 \cdot 4$ & $72 \cdot 0$ & $7 \cdot 3$ \\
\hline Control 7 & $91 \cdot 6 \%$ & $\mathrm{R}$ & $58 \cdot 8 \%$ & $\mathrm{U}$ & $42 \cdot 4$ & $68 \cdot 1$ & $18 \cdot 8$ \\
\hline Control 8 & $69 \cdot 4 \%$ & $\mathrm{U}$ & $63 \cdot 0 \%$ & $\mathrm{U}$ & $76 \cdot 5$ & $73 \cdot 4$ & $10 \cdot 1$ \\
\hline Control 9 & $85 \cdot 5 \%$ & $\mathrm{R}$ & $96 \cdot 3 \%$ & S & $56 \cdot 9$ & $54 \cdot 2$ & $8 \cdot 8$ \\
\hline Control 10\# & $-\#$ & & $64 \cdot 1 \%$ & $\mathrm{U}$ & $66 \cdot 9$ & $-\#$ & $-\#$ \\
\hline Control 11 & $90 \cdot 7 \%$ & $\mathrm{R}$ & $92 \cdot 2 \%$ & S & $82 \cdot 3$ & $80 \cdot 8$ & $25 \cdot 1$ \\
\hline Control 12 & $92 \cdot 4 \%$ & $S$ & $90 \cdot 4 \%$ & $\mathrm{R}$ & $56 \cdot 1$ & $64 \cdot 8$ & $5 \cdot 7$ \\
\hline Control 13 & $92 \cdot 3 \%$ & $S$ & $84 \cdot 6 \%$ & $\mathrm{R}$ & $88 \cdot 2$ & $86 \cdot 1$ & $1 \cdot 8$ \\
\hline Control 14 & $69 \cdot 9 \%$ & $\mathrm{U}$ & $96 \cdot 7 \%$ & S & $61 \cdot 9$ & $76 \cdot 7$ & $14 \cdot 1$ \\
\hline Control 15 & $68 \cdot 2 \%$ & $\mathrm{U}$ & $90 \cdot 2 \%$ & $\mathrm{R}$ & $72 \cdot 8$ & $81 \cdot 5$ & $8 \cdot 7$ \\
\hline Control 16 & $92 \cdot 4 \%$ & $S$ & $85 \cdot 4 \%$ & $\mathrm{R}$ & $31 \cdot 1$ & $42 \cdot 4$ & $4 \cdot 8$ \\
\hline Mean $\pm S D$ & $83 \cdot 4 \pm 10 \cdot 8$ & & $84 \cdot 8 \pm 11 \cdot 8$ & & $70 \cdot 2 \pm 16 \cdot 7$ & $72 \cdot 1 \pm 12 \cdot 2$ & $13 \cdot 9 \pm 10 \cdot 8$ \\
\hline Range & $68 \cdot 2-94 \cdot 2$ & & $58 \cdot 8-96 \cdot 7$ & & $31 \cdot 1-88 \cdot 7$ & $42 \cdot 4-86 \cdot 4$ & $1 \cdot 8-42 \cdot 0$ \\
\hline
\end{tabular}


with non-target organisms when compared to the bacterial signal of the Bact338-IIA probe. Assuming that the background signal with the Chis 150 probe is more or less the same from all mixed bacterial populations, the C. histolyticum group contributed a mean of 3-5\% of the total population, which is still higher than the previously reported $<1 \%$. The proportions of the C. leptum group found in control subjects (mean 12 and $9 \%$, for baseline and 6 month samples, respectively) and IBS subjects (mean 12 and $15 \%$, for baseline and 6 month samples, respectively) were in agreement with earlier studies (Sghir et al., 2000; Marteau et al., 2001; Hold et al., 2002).

In the present study, the C. coccoides-E. rectale group was the dominant subgroup of faecal clostridia. It contributed a mean of $43 \%$ (range $18-71 \%$ ) of the total bacteria in control subjects, and 30\% (constipation type) to $50 \%$ (diarrhoea type) (range 14-68\%) in different IBS symptom category subjects. The mean percentage observed with our control subjects is somewhat higher than the previously reported 11-35\% (range 5-45\%) for healthy adults (Franks et al., 1998; Jansen et al., 1999; Sghir et al., 2000; Marteau et al., 2001; Harmsen et al., 2002a, b; Zoetendal et al., 2002; Hold et al., 2003; Rigottier-Gois et al., 2003; Rochet et al., 2004). This highlights interindividual differences that are possibly due to diet and genetic background. In addition, the age distribution in both our subject groups was wider than that of most other studies. Furthermore, it should be noted that the smaller proportions of the $C$. coccoides- $E$. rectale group in other studies compared to our results have been obtained with fluorescent in situ hybridization (FISH) [except for the studies of Sghir et al. (2000) and Marteau et al. (2001)], whereas the results of Rigottier-Gois et al. (2003) obtained with dot-blot hybridization (mean $22 \%$ ) were more similar to those of our study (range $12-55 \%$ versus $18-71 \%$ in our study). The FISH analysis measures the proportion of the cells that contain a sufficient number of ribosomes to be detected, while rRNA dot-blot hybridization gives an index that reflects the ribosomal content of the cells and the general metabolic activity (Rigottier-Gois et al.,
2003), as does the TRAC technique. The amount of rRNA per cell varies according to the species and the metabolic activity of the bacterial cell (Klappenbach et al., 2000). When the human faecal microbiota has been analysed with the $16 \mathrm{~S}$ rDNA library method, bacteria from the C. coccoides- $E$. rectale group have contributed $10-59 \%$ of the total faecal flora (Wilson \& Blitchington, 1996; Suau et al., 1999; Hayshi et al., 2002; Hold et al., 2002; Wang et al., 2003), which is in accordance with our results.

No difference was observed in the present study in the proportions of the C. coccoides-E. rectale group when all IBS subjects together were compared to the control subjects (Table 3). However, when different IBS symptom categories were compared to the control subjects, the proportion of the C. coccoides-E. rectale group of clostridia was significantly lower in the constipation-type IBS subjects than in the control subjects, and also at the 6 months sampling timepoint of the mixed-type IBS subjects $(P<0 \cdot 05)$ (Table 3$)$. Similar differences have been observed by Malinen et al. (2005). In contrast to this, Rinttilä et al. (2004) have found with real-time PCR that the number of cells belonging to the C. coccoides-E. rectale group is somewhat lower in the IBS group than in the control group. However, their subject groups contain only three subjects. As a target clostridial group, the $C$. coccoides- $E$. rectale group (phylogenetic clusters XIVa and $\mathrm{XIVb}$ ) is too large to detect subtle variations between the microbiota of control and IBS subjects, and therefore needs to be divided into smaller subgroups in further studies.

\section{Temporal stability of clostridial populations}

No clear differences in intraindividual temporal stability (change in proportions between the two sampling points) of the $C$. leptum, $C$. lituseburense and $C$. coccoides- $E$. rectale groups were observed between the IBS and control subjects. However, the $C$. histolyticum group was temporally more stable (the change in proportions of the C. histolyticum groups was smaller) in mixed-type IBS subjects than in the

\section{Table 2. cont.}

\footnotetext{
${ }^{*}$ Similarity values were counted with BioNumerics 3.0 software. Clustering was performed with Pearson correlation and the unweighted pair group method with arithmetic mean (UPGMA). Amplicons with a total surface area of at least $1 \%$ were included in the similarity analysis. †Quantitative $\Delta$ clostridia (\%) indicated the total change of clostridia as measured by the TRAC technique, which was defined as: absolute change $(\Delta$; percentage at baseline minus percentage at 6 months) in the Clept-hybridized population + absolute change $(\Delta)$ in Clit-hybridized population + absolute change $(\Delta)$ in Chis-hybridized population + absolute change $(\Delta)$ in Erec-hybridized population. See Table 1 for meanings of abbreviations.

$\ddagger$ Similarity value thresholds indicating stable, rather stable or unstable DGGE profiles were determined according to the visual inspection of two researchers. Similarity value thresholds for RNA-based and DNA-based profiles were determined separately.

§RNA-based similarity thresholds: stable $(>92 \cdot 2 \%)$, rather stable $(70 \cdot 0-92 \cdot 1 \%)$, unstable $(<70 \cdot 0 \%)$.

IIDNA-based similarity thresholds: stable $(>92 \cdot 2 \%)$, rather stable $(75 \cdot 0-92 \cdot 1 \%)$, unstable $(<75 \cdot 0 \%)$.

TThe RNA of the second sample (time-point 6 months) of the subject IBS 11 did not amplify with RT-PCR sufficiently (for DGGE), regardless of various modifications to the protocol.

\#The quality and amount of RNA of the second sample (time-point 6 months) of the subject Control 10 was not sufficient either for RT-PCR or the quantitative TRAC analysis. RNA was extracted three times with two different methods.
} 
Table 3. Proportions of studied groups of clostridia, as quantified with the TRAC technique from faecal samples of IBS subjects and control subjects on two sampling occasions

See Table 1 for meanings of abbreviations. Values show the percentage of the hybridized total bacteria (with Bact338-IIA probe), mean \pm SD. Values in bold type show a statistically significant difference $(P<0 \cdot 05)$ compared to the control subject group.

\begin{tabular}{|c|c|c|c|c|c|c|c|c|}
\hline Group (number of subjects) & \multicolumn{8}{|c|}{ Probe } \\
\hline \multicolumn{9}{|l|}{ Diarrhoea type (7) } \\
\hline Proportion & $11 \cdot 0 \pm 4 \cdot 7$ & $14 \cdot 0 \pm 4 \cdot 3$ & $1 \cdot 1 \pm 2 \cdot 1$ & $0 \cdot 4 \pm 0 \cdot 4$ & $6 \cdot 7 \pm 1 \cdot 5$ & $5 \cdot 3 \pm 1 \cdot 1$ & $49 \cdot 8 \pm 10 \cdot 5$ & $45 \cdot 9 \pm 10 \cdot 1$ \\
\hline Range (of proportion) & $4 \cdot 3-16 \cdot 8$ & $8 \cdot 4-22 \cdot 2$ & $0 \cdot 1-5 \cdot 9$ & $0 \cdot 0-1 \cdot 0$ & $5 \cdot 4-9 \cdot 2$ & $4 \cdot 0-7 \cdot 3$ & $38 \cdot 6-68 \cdot 2$ & $30 \cdot 2-60 \cdot 7$ \\
\hline Range (of change in proportion) & & $0 \cdot 8-17 \cdot 9$ & & $0-5 \cdot 6$ & & $0 \cdot 1-2 \cdot 7$ & & $1 \cdot 6-30 \cdot 9$ \\
\hline Total change of clostridia & & & & & & & & $15 \cdot 0 \pm 16 \cdot 2$ \\
\hline \multicolumn{9}{|l|}{ Constipation type (6) } \\
\hline Proportion & $14 \cdot 5 \pm 5 \cdot 4$ & $14 \cdot 8 \pm 8 \cdot 1$ & $1 \cdot 6 \pm 1 \cdot 1$ & $3 \cdot 9 \pm 2 \cdot 5$ & $5 \cdot 9 \pm 1 \cdot 6$ & $7 \cdot 1 \pm 3 \cdot 0$ & $33 \cdot 8 \pm 5 \cdot 2$ & $29 \cdot 5 \pm 9 \cdot 4$ \\
\hline Range (of proportion) & $5 \cdot 5-20 \cdot 1$ & $5 \cdot 5-25 \cdot 1$ & $0 \cdot 4-3 \cdot 3$ & $0 \cdot 5-8 \cdot 0$ & $3 \cdot 1-7 \cdot 9$ & $3 \cdot 1-10 \cdot 4$ & $24 \cdot 8-38 \cdot 7$ & $14 \cdot 0-40 \cdot 0$ \\
\hline Proportion & $11 \cdot 5 \pm 4 \cdot 9$ & $17 \cdot 0 \pm 10 \cdot 6$ & $2 \cdot 2 \pm 0 \cdot 6$ & $3 \cdot 2 \pm 0 \cdot 2$ & $5 \cdot 6 \pm 1 \cdot 3$ & $6 \cdot 7 \pm 0 \cdot 8$ & $33 \cdot 6 \pm 8 \cdot 4$ & $30 \cdot 7 \pm 8 \cdot 1$ \\
\hline Range (of proportion) & $7 \cdot 0-16 \cdot 7$ & $8 \cdot 7-29 \cdot 0$ & $1 \cdot 7-2 \cdot 9$ & $3 \cdot 0-3 \cdot 4$ & $4 \cdot 6-7 \cdot 0$ & $5 \cdot 8-7 \cdot 4$ & $27 \cdot 3-43 \cdot 1$ & $22 \cdot 2-38 \cdot 4$ \\
\hline Change in proportionll & & $5 \cdot 5 \pm 5 \cdot 9$ & & $1 \cdot 0 \pm 0 \cdot 8$ & & $1 \cdot 2 \pm 0 \cdot 8$ & & $5 \cdot 7 \pm 2 \cdot 1$ \\
\hline Range (of change in proportion) & & $1 \cdot 7-12 \cdot 3$ & & $0 \cdot 1-1 \cdot 6$ & & $0 \cdot 4-1 \cdot 9$ & & $4 \cdot 3-8 \cdot 1$ \\
\hline Total change of clostridia & & & & & & & & $13 \cdot 3 \pm 6 \cdot 3$ \\
\hline \multicolumn{9}{|l|}{ Overall mean of IBS subjects (16) } \\
\hline Proportion & $12 \cdot 4 \pm 4 \cdot 9$ & $14 \cdot 9 \pm 6 \cdot 8$ & $1 \cdot 5 \pm 1 \cdot 6$ & $2 \cdot 3 \pm 2 \cdot 2$ & $6 \cdot 2 \pm 1 \cdot 5$ & $6 \cdot 5 \pm 2 \cdot 1$ & $40 \cdot 7 \pm 11 \cdot 4$ & $36 \cdot 9 \pm 12 \cdot 1$ \\
\hline Range (of proportion) & $4 \cdot 3-20 \cdot 1$ & $5 \cdot 5-29 \cdot 0$ & $0 \cdot 1-5 \cdot 9$ & $0 \cdot 0-8 \cdot 0$ & $3 \cdot 1-9 \cdot 2$ & $3 \cdot 1-10 \cdot 4$ & $24 \cdot 8-68 \cdot 2$ & $14 \cdot 0-60 \cdot 7$ \\
\hline Change in proportionll & & $3 \cdot 8 \pm 4 \cdot 9$ & & $1 \cdot 5 \pm 2 \cdot 1$ & & $1 \cdot 4 \pm 1 \cdot 0$ & & $7 \cdot 2 \pm 8 \cdot 2$ \\
\hline Range (of change in proportion) & & $0-17 \cdot 9$ & & $0-7 \cdot 4$ & & $0-3 \cdot 9$ & & $0 \cdot 4-30 \cdot 9$ \\
\hline Total change of clostridia & & & & & & & & $13 \cdot 9 \pm 12 \cdot 2$ \\
\hline \multicolumn{9}{|l|}{ Control subjects (16) } \\
\hline
\end{tabular}

*The Clept1240 probe (Sghir et al., 2000) targets the C. leptum group, which corresponds to clostridial phylogenetic cluster IV (Collins et al., 1994).

$\dagger$ The Clit135 probe (Franks et al., 1998) targets the C. lituseburense group, which corresponds to clostridial phylogenetic cluster XI (Collins et al., 1994).

$\ddagger$ The Chis150 probe (Franks et al., 1998) targets the C. histolyticum group, which corresponds to clostridial phylogenetic clusters I and II (Collins et al., 1994).

\$The Erec482 probe (Franks et al., 1998) targets the C. coccoides-E. rectale group, which corresponds to clostridial phylogenetic clusters XIVa and XIVb (Collins et al., 1994).

IIThe change was defined as: absolute change ( $\Delta$; percentage at baseline minus percentage at 6 months) in the population.

The total change of clostridia was defined as: absolute change $(\Delta$; percentage at baseline minus percentage at 6 months) in Clept-hybridized population + absolute change $(\Delta)$ in Clit-hybridized population + absolute change $(\Delta)$ in Chis-hybridized population + absolute change $(\Delta)$ in Erec-hybridized population.

control subjects $(P=0 \cdot 05)$ (Table 3$)$. Altogether, there was mostly smaller temporal variation in the studied clostridial groups than interindividual variation, and this has also been reported by Matsuki et al. (2004). However, the instability of predominant bacteria was also seen in the change of the proportions of the studied clostridial groups (Tables 2 and 
3) in our study. Subjects whose predominant bacterial population (by RT-PCR-DGGE) was unstable over the studied time-period had a significant change in the proportions of the clostridial groups between the two sampling points (baseline and 6 months) when compared to the subjects whose predominant bacterial population was stable $(P<0 \cdot 05)$. This might be expected, since the studied clostridial groups represented the dominant faecal microbiota in these subjects. The same was also noticed with DNA-based DGGE profiles, but the difference with DNAbased profiles was not statistically significant $(P=0 \cdot 06)$.

\section{Conclusions}

The differences in faecal bacterial population between IBS and control subjects have been reported in several studies (Balsari et al., 1982; Bradley et al., 1987; Madden \& Hunter, 2002; Mättö et al., 2005). We found a marked difference in the proportions of the $C$. coccoides-E. rectale group of clostridia between constipation-type IBS subjects and control subjects. In addition, there was more instability in the DGGE profiles derived from faecal RNA amplicons of the IBS subjects than those of the control subjects. However, further studies are needed with larger subject groups to confirm these findings.

\section{ACKNOWLEDGEMENTS}

This study was supported by the Finnish Technology Centre (Tekes grant 954/401/00) and the Academy of Finland. Ms Marja-Liisa Jalovaara is greatly acknowledged for her excellent technical assistance.

\section{REFERENCES}

Amann, R. I., Binder, B. J., Olson, R. J., Chisholm, S. W., Devereux, R. \& Stahl, D. A. (1990). Combination of $16 S$ rRNA-targeted oligonucleotide probes with flow cytometry for analyzing mixed microbial populations. Appl Environ Microbiol 56, 1919-1925.

Balsari, A., Ceccarelli, A., Dubini, F., Fesce, E. \& Poli, G. (1982). The fecal microbial population in the irritable bowel syndrome. Microbiologica 5, 185-194.

Bartosch, S., Fite, A., Macfarlane, G. T. \& McMurdo, M. E. T. (2004). Characterization of bacterial communities in feces from healthy elderly volunteers and hospitalized elderly patients by using real-time PCR and effects of antibiotic treatment on the fecal microbiota. Appl Environ Microbiol 70, 3575-3581.

Bradley, H. K., Wyatt, G. M., Bayliss, C. E. \& Hunter, J. O. (1987). Instability in the faecal flora of a patient suffering from food-related irritable bowel syndrome. J Med Microbiol 23, 29-32.

Bustin, S. A. \& Nolan, T. (2004). Pitfalls of quantitative real-time reverse-transcription polymerase chain reaction. J Biomol Techniq 15, 155-166.

Cato, E. P., George, W. L. \& Finegold, S. M. (1986). Genus Clostridium Prazmowski 1880. In Bergey's Manual of Systematic Bacteriology, vol. 2, pp. 1141-1200. Edited by P. H. A. Sneath, N. S. Mair, M. E. Sharpe \& J. G. Holt. Baltimore, MD: Williams \& Wilkins.

Collins, M. D., Lawson, P. A., Willems, A., Cordoba, J. J., FernandezGarayzabal, J., Gaecia, P., Cai, J., Hippe, H. \& Farrow, J. A. E.
(1994). The phylogeny of the genus Clostridium: proposal of five new genera and eleven new species combinations. Int J Syst Bacteriol 144, 812-826.

Donskey, C. J., Hujer, A. M., Das, S. M., Pultz, N. J., Bonomo, R. A. \& Rice, L. B. (2003). Use of denaturing gradient gel electrophoresis for analysis of the stool microbiota of hospitalized patients. J Microbiol Methods 54, 249-256.

Edlund, C. \& Nord, C. E. (2000). Effect on the human normal microflora of oral antibiotics for treatment of urinary tract infections. J Antimicrob Chemother 46, Supplement S1, 41-48.

Felske, A., Rheims, H., Wolterink, A., Stackebrandt, E. \& Akkermans, A. D. L. (1997). Ribosome analysis reveals prominent activity of an uncultured member of the class Actinobacteria in grassland soils. Microbiology 143, 2983-2989.

Franks, A. H., Harmsen, H. J. M., Raangs, G. C., Jansen, G. J., Schut, F. \& Welling, G. W. (1998). Variations in bacterial populations in human feces measured by fluorescent in situ hybridization with groupspecific 16S rRNA-targeted oligonucleotide probes. Appl Environ Microbiol 64, 3336-3345.

Harmsen, H. J. M., Gibson, G. R., Elfferich, P., Raangs, G. C., Wideboer-Veloo, A. C. M., Argaiz, A., Roberfroid, M. B. \& Welling, G. W. (1999). Comparison of viable cell counts and fluorescence in situ hybridization using specific rRNA-based probes for the quantification of human fecal bacteria. FEMS Microbiol Lett 183, 125-129.

Harmsen, H. J. M., Raangs, G. C., Franks, A. H., Wildeboer-Veloo, A. C. M. \& Welling, G. W. (2002a). The effect of the prebiotic inulin and the probiotic Bifidobacterium longum in the fecal microflora of healthy volunteers measured by FISH and DGGE. Microbiol Ecol Health Disease 14, 211-219.

Harmsen, H. J. M., Raangs, G. C., He, T., Degener, J. E. \& Welling, G. W. (2002b). Extensive set of $16 \mathrm{~S}$ rRNA-based probes for detection of bacteria in human feces. Appl Environ Microbiol 68, 2982-2990.

Hayshi, H., Sakamoto, M. \& Benno, Y. (2002). Phylogenetic analysis of the human gut microbiota using 16S rDNA clone libraries and strictly anaerobic culture-based methods. Microbiol Immunol 46, 535-548.

Hold, G. L., Pryde, S. E., Russell, V. J., Furrie, E. \& Flint, H. J. (2002). Assessment of microbial diversity in human colonic samples by $16 \mathrm{~S}$ rDNA sequence analysis. FEMS Microbiol Ecol 39, 33-39.

Hold, G. L., Schwiertz, A., Aminov, R. I., Blaut, M. \& Flint, H. J. (2003). Oligonucleotide probes that detect quantitatively significant groups of butyrate-producing bacteria in human feces. Appl Environ Microbiol 69, 4320-4324.

Jansen, G. J., Wilderboer-Veloo, A. C. M., Tonk, R. H. J., Franks, A. H. \& Welling, G. W. (1999). Development and validation of an automated, microscopy-based method for enumeration of groups of intestinal bacteria. J Microbiol Methods 37, 215-221.

Josephson, K. L., Gerba, C. P. \& Pepper, I. L. (1993). Polymerase chain reaction detection of nonviable bacterial pathogens. Appl Environ Microbiol 59, 3513-3515.

King, T. S., Elia, M. \& Hunter, J. O. (1998). Abnormal colonic fermentation in irritable bowel syndrome. Lancet 352, 1187-1189.

Klappenbach, J. A., Dunbar, J. M. \& Schmidt, T. M. (2000). rRNA operon copy number reflects ecological strategies of bacteria. Appl Environ Microbiol 66, 1328-1333.

Madden, J. A. J. \& Hunter, J. O. (2002). A review of the role of the gut microflora in irritable bowel syndrome and the effects of probiotics. Br J Nutr 88, S67-S72.

Malinen, E., Rinttilä, T., Kajander, K., Mättö, J., Kassinen, A., Krogius, L., Saarela, M., Korpela, R. \& Palva, A. (2005). Realtime PCR analysis reveals differences between the fecal microbiota 
of irritable bowel syndrome patients and healthy controls. Am J Gastroenterol 100, 373-382.

Mangin, I., Bonnet, R., Seksik, P. \& 8 other authors (2004). Molecular inventory of faecal microflora in patients with Crohn's disease. FEMS Microbiol Ecol 50, 25-36.

Marteau, P., Pochart, P., Doré, J., Béra-Maillet, C., Bernalier, A. \& Corthier, G. (2001). Comparative study of bacterial groups within the human cecal and fecal microbiota. Appl Environ Microbiol 67, 4939-4942.

Matsuki, T., Watanabe, K., Fujimoto, J., Takada, T. \& Tanaka, R. (2004). Use of $16 \mathrm{~S}$ rRNA gene-targeted group-specific primers for real-time PCR analysis of predominant bacteria in human feces. Appl Environ Microbiol 70, 7220-7228.

Mättö, J., Maunuksela, L., Kajander, K., Palva, A., Korpela, R., Kassinen, A. \& Saarela, M. (2005). Composition and temporal stability of gastrointestinal microbiota in irritable bowel syndrome a longitudinal study in IBS and control subjects. FEMS Immunol Med Microbiol 43, 213-222.

Nübel, U., Engelen, B., Felske, A., Snaidr, J., Wieshuber, A., Amann, R. I., Ludwig, W. \& Backhaus, H. (1996). Sequence heterogeneities of genes encoding $16 \mathrm{~S}$ rRNAs in Paenibacillus polymyxa detected by temperature gradient gel electrophoresis. J Bacteriol 178, 5636-5643.

Pimentel, M., Chow, E. J. \& Lin, H. C. (2000). Eradication of small intestinal bacterial overgrowth reduces symptoms of irritable bowel syndrome. Am J Gastroenterol 95, 3503-3506.

Rigottier-Gois, L., Le Bourhis, A.-G., Gramet, G., Rochet, V. \& Doré, J. (2003). Fluorescent hybridisation combined with flow cytometry and hybridisation of total RNA to analyse the composition of microbial communities in human faeces using 16S rRNA probes. FEMS Microbiol Ecol 43, 237-245.

Rinttilä, T., Kassinen, A., Malinen, E., Krogius, L. \& Palva, A. (2004). Development of an extensive set of $16 \mathrm{~S}$ rDNA-targeted primers for quantification of pathogenic and indigenous bacteria in faecal samples by real-time PCR. J Appl Microbiol 97, 1166-1177.

Rochet, V., Rigottier-Gois, L., Rabot, S. \& Doré, J. (2004). Validation of fluorescent in situ hybridization combined with flow cytometry for assessing interindividual variation in the composition of human fecal microflora during long-term storage of samples. J Microbiol Methods 59, 263-270.

Satokari, R. M., Kataja, K. \& Söderlund, H. (2005). Multiplexed quantification of bacterial $16 \mathrm{~S}$ rRNA by solution hybridization with oligonucleotide probes and affinity capture. Microb Ecol 50, 120-127.

Seksik, P., Rigottier-Gois, L., Gramet, G., Sutren, M., Pochart, P., Marteau, P., Jian, R. \& Doré, J. (2003). Alterations of the dominant faecal bacterial groups in patients with Crohn's disease of the colon. Gut 52, 237-242.

Sghir, A., Gramet, G., Suau, A., Rochet, V., Pochart, P. \& Doré, J. (2000). Quantification of bacterial groups within human fecal flora by oligonucleotide probe hybridization. Appl Environ Microbiol 66, 2263-2266.

Suau, A., Bonnet, R., Sutren, M., Godon, J.-J., Gibson, G., Collins, M. D. \& Doré, J. (1999). Direct analysis of genes encoding $16 \mathrm{~S}$ rRNA from complex communities reveals many novel molecular species within the human gut. Appl Environ Microbiol 65, 4799-4807.

Tannock, G. W., Munro, K., Biniloni, R., Simon, M. A., Hargreaves, P., Gopal, P., Harmsen, H. \& Welling, G. (2004). Impact of consumption of oligosaccharide-containing biscuits on the fecal microbiota of humans. Appl Environ Microbiol 70, 2129-2136.

Thompson, W. G., Longstreth, G. F., Drossman, D. A., Heaton, K. W., Irvine, E. J. \& Müller-Lissner, S. A. (1999). Functional bowel disorders and functional abdominal pain. Gut 45, supplement 2, II43-II47.

Vanhoutte, T., Huys, G., De Brandt, E. \& Swings, J. (2004). Temporal stability analysis of the microbiota in human feces by denaturing gradient gel electrophoresis using universal and group-specific 16S rRNA gene primers. FEMS Microbiol Ecol 48, 437-446.

Wang, X., Heazlewood, S. P., Krause, D. O. \& Florin, T. H. J. (2003). Molecular characterization of the microbial species that colonize human ileal and colonic mucosa by using $16 \mathrm{~S}$ rDNA sequence analysis. J Appl Microbiol 95, 508-520.

Wilson, K. H. \& Blitchington, R. B. (1996). Human colonic biota studied by ribosomal DNA sequence analysis. Appl Environ Microbiol 62, 2273-2278.

Zoetendal, E. G., Akkermans, A. D. \& de Vos, W. M. (1998). Temperature gradient gel electrophoresis analysis of 16S rRNA from human fecal samples reveals stable and host-specific communities of active bacteria. Appl Environ Microbiol 64, 3854-3859.

Zoetendal, E. G., Akkermans, A. D. L., Akkermans-van Vliet, W. M., de Visser, J. A. G. M. \& de Vos, W. M. (2001). The host genotype affects the bacterial community in the human gastrointestinal tract. Microbiol Ecol Health Dis 13, 129-134.

Zoetendal, E. G., Ben-Amor, K., Harmsen, H. J. M., Schut, F., Akkermans, A. D. L. \& de Vos, W. M. (2002). Quantification of uncultured Ruminococcus obeum-like bacteria in human fecal samples by fluorescent in situ hybridization and flow cytometry using 16S rRNA-targeted probes. Appl Environ Microbiol 68, 4225-4232. 